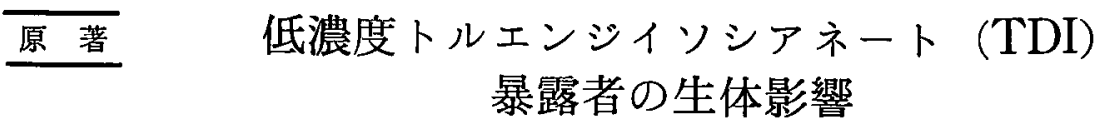

谷枷 弘茂*, 島正吾*, 立川 壮一*, 加藤 保夫*, 吉田 勉*

伊藤 哲也*, 長岡 莐*, 由利 卓也*, 細田 浩*, 三木 知子*

\title{
A STUDY ON THE IMMUNOLOGIC EFFECTS IN WORKERS EXPOSED TO LOW LEVELS OF TOLUENE-DIISOCYANATE (TDI)
}

\author{
Hiroshige Taniwaki, * Shogo ShIma,* Souichi Tachikawa,* Yasuo Kato,* \\ Tsutomu YoshIDA,* Tetsuya ITo,* Kaoru NAGAOKA,* Takuya YURI,* \\ Hiroshi HosodA* and Tomoko MIKI*
}

\begin{abstract}
Forty-three workers exposed to low levels of toluene diisocyanate (TDI) during the process of producing polyurethane forms were examined immunologically for IgG, A, M, and $E$ and serum enzyme activities such as serum angiotensin converting enzyme (SACE), serum lysozyme (SLZM) and glycylproline dipeptidyl aminopeptidase (GP-DAP). Air concentration of TDI was annually measured in various places of work during the past five years from 1979 to 1983 . The results obtained in the present study were as follows.
\end{abstract}

1. The air concentration of TDI at all places of work was below the permissible concentration level of $0.02 \mathrm{ppm}$ throughout the study period.

2. Subjective symptoms and abnormal findings on chest X-ray considered directly related to TDI exposure were not observed.

3. No remarkable abnormal findings in blood cell counts and in serum biochemical studies could be seen in any of the workers.

4. The serum IgG levels in workers directly exposed to TDI were significantly higher $(p<$ $0.05)$ than those in workers indirectly exposed to TDI and in non-exposed workers.

5. In the study of serum enzymatic activity, SLZM activity in workers exposed directly to TDI was significantly higher $(p<0.01)$ than those in workers indirectly exposed to TDI and in non-exposed workers.

Key words : toluene diisocyanate exposure; immunological study; serum angiotensin converting enzyme; serum lysozyme

I.はじめに

トルエンジイソシアネート (toluene-diisocyanate, TDI）は分子量 174 の低分子化合物で，2 個の反応性の 強いイソシアネート基を有し，ウレタン結合，ウレイド 結合を形成して高分子化合物ポリウレタンを生成する. ポリウレタンは, マットレス, 自動車部品, 断熱材, シ ーリング材等に広く使用されている，我が国では 1960

* 滕田学園保健衛生大学医学部公潘衛生学教室 昭和61年 6 月 6 日受付

* Department of Public Health, Fujita.Gakuen Health University School of Medicine

Received for publication, June 6, 1986
年頃よりポリウレタン製造が国産化し，生産規模，需要 の急速な増加に伴い，作業者への健康障害が問題となっ てきた。しかし現在では作業現場の環境改善，作業者の 健康管理対策がある程度実をあげ急性大量暴露は認めら れなくなり，むしろ慢性低濃度暴露の生体影響が重要な 課題となってきている. TDI による健康障害について

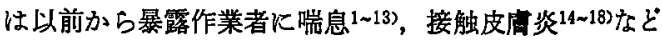
の一連のフレルギー症状が発現することが報告されてお。 り，そのメカニズムとして Sheel ら ${ }^{19)}$ は TDI が蛋白 質と反応して感作源となることを実驗的に示唆してい る.またTDIによるアレルギー反応の出現は，PCA 反 応 $^{203}$, リンパ球幼若化反応 ${ }^{212}$ ，吸入誘発試験7,11,13) 等の 臨床的成績によってる襄つけられている.さらに最近で 
は TDI 暴露者に特異的な IgE 22 24), IgG'24) の存在する ことや，過敏性肺炎 $4,9,24)$ の発症子報告されており，I 型，血型に加えてIV型アレルギーの関与す示咬されてい る. 今回我々は TDI 低浱度暴露環境下にある某ウレタ ン制造工場作業者を対象に，主として血清免疫学的検查 を中心に 5 年間にわたる TDI 暴露作業者に対する健康 影暨を検討したので報告する。

\section{II. 対象および方法}

愛知県下で主として自動車用のウレタンバンパー，シ ート，ヘッドレスト，インストルメンタルバネル等を生 産している某ポリウレタン樹脂工場作業者 150 名のう ら，5年以上の作業歴をるつ 63 名を対象とした，当工 場に柇けるウレタン製品の製造工程は，TDI，ポリオー ル(またはボリェステル)，アミンおよび水を主原料と して，機械混合液の調合 (閉鎖的処理)，原料液の金型 注入, 発泡, 半製品の離型, 離型剂塗布扡よび金型整備 がライン作業として行なわれている. 対象作業者はこれ らのラインに直接従事し，常時 TDI 暴露を受ける者と ライン作業以外の製品の仕上げ，運搬作業，雑役等に從 事し，間接的に TDI 暴露を受ける者の 2 群とした. 以 下の検討では前者を直接暴露群 19 名 (A群)，後者を間 接暴露群 24 名 (B群) とした。 また本調查の対照群（C 群）として，胸部 X線検查上異常所見を認めず，既往に おいて有害業務の作業歷のない健常事務職員 20 名を選 んた. 健康調查は全員に対して血清免疫学的検查，末梢 血液榆査, 血清酵素学的検查拈よび血清生化学的検查を 実施し，あわせて昭和 54 年から 58 年までの 5 年間の気 中 TDI 濃度湘定について子検討した.

血液生化学検査は, Glutamic oxaloacetic transaminase (GOT), Glutamate pyruvate transaminase GPT) は Reitman-Frankel 法, Lactic dehydrogenase
(LDH)は Dinitrophenylhydrazine 法, Alkaline phosphatase (ALP) は Kind-King 法, Creatinine は Jaffe 法, Blood urea nitrogen (BUN) は Ureaseindophenol 法によって実施し，GOT，GPT，ALP，LDH および Creatinine は和光純薬の臨床検查キット, BUNは富士 臓器社製キットを用い，それぞれ Endpoint 法で測定し た.

血清酵素学的娭査は, Serum angiotensin converting enzyme (SACE) を笠原らの方法 ${ }^{25}$ に基づき, ACE color（富士レビオ社製測定用キット）を用いた比色法で 測定した. Serum lysozyme (SLZM)は, Micrococcus lysodeiticus（生化学工業社製）を基質とした比濁法 ${ }^{26)}$ で測定した. Glycylproline dipeptidyl aminopeptidase (GP-DAP) は, 勘質グリシルプロリル・p-ニトロアニ リド・トシレート（富士レビオ社製測定用キット）を用 い，永津らの方法27で測定した。

血清免疫グロブリンについては IgG，A， M， E を測 定し，IgG，A，M はへキスト社製トリパルチゲンを用 い，免疫拻散法で定量した. また IgE は同社の LC ハ ルチゲンを用い，免疫拡散法で半定量した。

環境気中 TDI の分析は，TDI を液体捕集法で捕集 後, ジゾ化, カップリング反応を用いる吸光光度分析 法 (Marcali method) で分析した.

\section{III. 成 績}

\section{1. 作業環境気中 TDI 濃度}

TDI 作業場に拉ける昭和 54 年から 5 年間にわたる TDI 気中濃度を年間平均值として Table 1 に示した. 各年間の平均気中浱度では $0.005 \sim 0.020 \mathrm{ppm}$ が娭出さ れこれらのうち最も高濃度の場所は注入Aラインであ り 5 年間 30 サンプルの平均気中濃度は $0.012 \mathrm{ppm}$ で あったがいずれの場所でる TDI 許容濃度の $0.02 \mathrm{ppm}$

Table 1. Air concentration of TDI.

\begin{tabular}{|c|c|c|c|c|c|c|c|c|}
\hline Work sites & $N^{*}$ & 1979 & 1980 & 1981 & 1982 & 1983 & Mean $\pm S D$ & $\min \sim \max$ \\
\hline Mixing & 2 & $(-)$ & $(-)$ & $(-)$ & $(-)$ & $(-)$ & $(-)$ & $(-)$ \\
\hline Pouring in line A & 6 & 0.012 & 0.005 & 0.012 & 0.020 & 0.015 & $0.012 \pm 0.005$ & $(-) \sim 0.021$ \\
\hline Pouring in line $B$ & 24 & $(-)$ & $(-)$ & $(-)$ & $(-)$ & $(-)$ & $(-)$ & $(-)$ \\
\hline Forming & 22 & 0.004 & $(-)$ & $(-)$ & $(-)$ & $(-)$ & $0.001 \pm 0.002$ & $(-) \sim 0.015$ \\
\hline $\begin{array}{l}\text { Spraying the mold } \\
\text { release agents }\end{array}$ & 4 & $(-)$ & $(-)$ & $(-)$ & 0.013 & 0.015 & $0.006 \pm 0.008$ & $(-) \sim 0.020$ \\
\hline Stripping & 6 & 0.005 & $(-)$ & $(-)$ & $(-)$ & $(-)$ & $0.002 \pm 0.003$ & $(-) \sim 0.021$ \\
\hline Reparing the metal molds & 2 & $(-)$ & $(-)$ & 0.020 & 0.020 & 0.015 & $0.006 \pm 0.005$ & $(-) \sim 0.020$ \\
\hline
\end{tabular}

(-) : lower detection limit value of $\mathrm{TDI}<0.004 \mathrm{ppm}, N^{*}:$ number of samples/year. 
Table 2. Peripheral blood findings.

\begin{tabular}{lccccc}
\hline & $\begin{array}{c}\mathrm{RBC} \\
\left(\times 10^{4} / \mathrm{mm}^{3}\right)\end{array}$ & $\begin{array}{c}\mathrm{WBC} \\
\left(\times 10^{2} / \mathrm{mm}^{3}\right)\end{array}$ & $\begin{array}{c}\mathrm{Ht} \\
(\%)\end{array}$ & $\begin{array}{c}\mathrm{Hb} \\
(\mathrm{g} / \mathrm{dl})\end{array}$ \\
\hline Group A & $461.6 \pm 45.8$ & $65.8 \pm 14.9$ & & $42.0 \pm 3.1$ & $14.8 \pm 1.2$ \\
Group B & $466.5 \pm 35.8$ & $64.2 \pm 15.5$ & & $43.5 \pm 2.8$ & $15.2 \pm 1.2$ \\
Group C & $463.9 \pm 40.4$ & $66.1 \pm 13.7$ & & $44.7 \pm 3.0$ & $15.1 \pm 1.1$ \\
\hline \hline & & \multicolumn{2}{c}{ Leucocyte differential } & & Monocyte \\
\hline Group A & Neutrophil & Eosinophil & Basophil & Limphocyte & $1.8 \pm 1.7$ \\
Group B & $64.8 \pm 10.4$ & $1.5 \pm 1.5$ & 0 & $30.1 \pm 10.8$ & $1.2 \pm 1.4$ \\
Group C & $67.7 \pm 10.3$ & $2.1 \pm 2.7$ & 0 & $29.8 \pm 7.7$ & $1.2 \pm 1.8$ \\
\hline
\end{tabular}

Table 3. Serum IgG, A, M and E levels and number with high levels $(920 \mathrm{IU}<)$ IgE.

\begin{tabular}{|c|c|c|c|c|}
\hline & $\operatorname{IgG}(\mathrm{mg} / \mathrm{dl})$ & $\operatorname{IgA}(\mathrm{mg} / \mathrm{dl})$ & $\mathrm{IgM}(\mathrm{mg} / \mathrm{dl})$ & $\operatorname{IgE}(920 \mathrm{IU}<)$ \\
\hline Group A & $\begin{array}{r}1,536.6 \pm 468.0^{*} \\
(2,603 \sim 1,149)\end{array}$ & $\begin{array}{c}201.9 \pm 78.8 \\
(428 \sim 118)\end{array}$ & $\begin{array}{l}\text { 124. } 1 \pm 29.9 \\
(177 \sim 68)\end{array}$ & $1 / 19[5.3 \%]$ \\
\hline Group B & $\begin{array}{c}1,298.5 \pm 189.7 \\
\quad(1,758 \sim 1,006)\end{array}$ & $\begin{array}{c}207.6 \pm 94.8 \\
(520 \sim 75)\end{array}$ & $\begin{array}{c}123.0 \pm 35.7 \\
(201 \sim 74)\end{array}$ & $4 / 24[16.6 \%]$ \\
\hline Group C & $\begin{array}{c}1,278.0 \pm 206.9 \\
(1,809 \sim 965)\end{array}$ & $\begin{array}{c}198.5 \pm 82.3 \\
(503 \sim 111)\end{array}$ & $\begin{array}{c}125.5 \pm 34.8 \\
(238 \sim 83)\end{array}$ & $0 / 20[0.0 \%]$ \\
\hline
\end{tabular}

( ) : Range of levels, ${ }^{*} p<0.05$.

を上回るるのはなかった，一方，配合および注入Bでは 完全な閉鎖式製造工程をとるため，いずれの測定であ気 中 TDI は検出されなかった（㢵出限度 : $0.004 \mathrm{ppm}$ 以 下).

\section{2. 対象作業者の概要}

TDI 直接（A群）あるいは間接暴露作業者（B群） 43 名および対照者（C群）20 名の平均年龄は，A群 $36.1 \pm 11.5$ 歳, B群 $34.7 \pm 8.3$ 歳, $C$ 群 $38.5 \pm 9.6$ 歳 であり, 膱歷はA 群 $10.8 \pm 2.6$ 年, $\mathrm{B}$ 群 $10.3 \pm 4.3$ 年, C群 9.8土5.2 年であった. いずれの対象に打いても TDI 以外の有害作業歴および家族歷等を有する者はな かった．既往歷では陳旧性肺結核，高血圧，胃溃㻛をそ れぞれ1名ずつ認めたがこれらは TDI 暴露との関連 性を認めなかった。

\section{3. 胸部 $\mathbf{X}$ 線所見}

対象 63 名について，昭和 54 年からの 5 年間に実施し た胸部 X線険查ではA 群に 1 名の陳旧性肺結核を認めた が，その他特記すべき異常所見はなかった。

\section{4. 末梢血液険查所見}

Table 2 のように, 貧血, 好酸球増多などの所見は認 めず， 3 群間の各検査成績は統計学的に有意差はなかっ
た.

\section{5. 血清免疫グロブリン検查所見}

Table 3 のように，IgA，IgM は，3群間に有意差を 認めず，また IgG は，A群 $(1,536.6 \pm 468.0 \mathrm{mg} / \mathrm{d})$ に打いて, B 群 $(1,298.5 \pm 189.7 \mathrm{mg} / \mathrm{dl}), C$ 群 $(1,278.0$ $\pm 206.9 \mathrm{mg} / \mathrm{dl})$ 上り有意な上昇を認めた $(p<0.05)$. 個々の対象の検討では，IgG 值 $1,800 \mathrm{mg} / \mathrm{dl}$ 以上を示 寸者がA群に 4 名認められ，5ち 3 名は 10 年以上の作 業者であった、しかしこの IgG 高值を示した者では， 自他覚的所見, 胸部X線検查所見飞異常を認めず，また 暴露濃度についても特定の傾向は認められなかった。 IgE は, $920 \mathrm{IU}$ 以上が A 群 1名 (5.3\%)，B群 4 名 (16.6\%)，C群 0名 $(0.0 \%)$ にあり，むしろA群より B 群に高值を示す者が目立った。

\section{6. 肝腎機能検查 (Table 4)}

肝機能および留機能值は，A，B，C 3 群のいずれに おいても異常を示す者はなく，また 3 群の成績には有意 差はなかった。

7. 血清酻素学的検查 (Table 6)

SLZM は，A群は B，C群飞比べて有意に高値を示し たが，SACE，GP-DAP 值は統計学的な有意差は認めな 
Table 4. Serum biochemical data.

\begin{tabular}{lcccccc}
\hline & $\begin{array}{c}\text { GOT } \\
(\mathrm{kU})\end{array}$ & $\begin{array}{c}\mathrm{GPT} \\
(\mathrm{kU})\end{array}$ & $\begin{array}{c}\mathrm{LDH} \\
(\mathrm{U})\end{array}$ & $\begin{array}{c}\text { ALP } \\
(\mathrm{kA})\end{array}$ & $\begin{array}{c}\mathrm{CRN} \\
(\mathrm{mg} / \mathrm{dl})\end{array}$ & $\begin{array}{c}\mathrm{BUN} \\
(\mathrm{mg} / \mathrm{dl})\end{array}$ \\
\hline Group A & $22.9 \pm 5.8$ & $17.4 \pm 7.7$ & $306.3 \pm 58.0$ & $6.6 \pm 3.2$ & $0.90 \pm 0.1$ & $14.9 \pm 2.7$ \\
Group B & $24.0 \pm 6.0$ & $26.5 \pm 12.4$ & $328.8 \pm 66.9$ & $5.9 \pm 2.2$ & $0.93 \pm 0.1$ & $14.7 \pm 2.9$ \\
Group C & $22.5 \pm 5.6$ & $20.9 \pm 11.2$ & $331.4 \pm 65.8$ & $5.7 \pm 2.2$ & $0.90 \pm 0.1$ & $13.1 \pm 2.3$ \\
\hline
\end{tabular}

Table 5. Serum enzyme activity.

\begin{tabular}{|c|c|c|c|}
\hline & $\begin{array}{l}\text { SLZM } \\
(\mu \mathrm{g} / \mathrm{ml})\end{array}$ & $\begin{array}{c}\mathrm{SACE} \\
(\mathrm{mU} / \mathrm{ml})\end{array}$ & $\begin{array}{l}\text { GP-DAP } \\
(\mathrm{mU} / \mathrm{ml})\end{array}$ \\
\hline Group A & $\begin{array}{l}6.67 \pm 1.65^{*} \\
(10.2 \sim 3.9)\end{array}$ & $\begin{array}{r}15.0 \pm 3.5 \\
(18.4 \sim 11.0)\end{array}$ & $\begin{array}{c}70.8 \pm 8.0 \\
(86.2 \sim 58.3)\end{array}$ \\
\hline Group B & $\begin{array}{c}5.85 \pm 1.55 \\
(8.1 \sim 4.0)\end{array}$ & $\begin{array}{r}15.5 \pm 3.5 \\
(20.6 \sim 5.2)\end{array}$ & $\begin{array}{c}74.8 \pm 21.1 \\
(142.0 \sim 52.3)\end{array}$ \\
\hline Group C & $\begin{array}{r}5.60 \pm 1.21 \\
(7.9 \sim 3.6)\end{array}$ & $\begin{array}{r}15.7 \pm 3.8 \\
(19.2 \sim 5.3)\end{array}$ & $\begin{array}{c}72.8 \pm 15.0 \\
(89.4 \sim 49.3)\end{array}$ \\
\hline
\end{tabular}

( ) : Range of activity, $* p<0.01$.

かった.

\section{IV. 考察}

TDI による健康影響は，化学的毒性による中毒 作 用 や粘膜刺激作用と生体感作による免度てレルギー作用が 知られている. 化学的毒性の発現は, TDI のインシア ネート基（-NCO）が非常に反応性が強く，活性水素を 有する物質と容易に反応するため28)と考克られている。

一方免疫フレルギー作用に関しては，リンパ球幼若化反 応, マクロファーシ遊走阻止試驗, P-K 反応, PCA 反 応, パッチテスト，兔疫グロプリン测定，好酸球测定， ヒスタミン遊離試験，TDI の吸入誘発試験等について 人ならびに実験動物に関する成績がみられ，体液性免 疫, 細胞性免疫の両面より多くの研究 $2,21,24,29,30,31)$ がな されている.さらに Karol ら222は, p-tolyl isocyanate (TNI) t human serum albumin (HSA) と結合させ た抗原を用いた Radioallergosorbent test(RAST) に拉 いて，TDI に感作している作業者では特異的 IgE 值の 上昇を認めたと報告し，TDI 暴露によるI型アレルギー の関与を示唆している. また Charles 54), 藤村 597, Zeiss ら ${ }^{24)}$ は MDI 括よび TDI による過敏性肺资の発 症を報告し，本症に対するIV型アレルギーの関与も示唆 されている.

今回我々は， 5 年以上の TDI 低漂度暴露歷をるつ作 業者について，その作業形態より直接暴露群と間接暴露 群の 2 群に分け, 対照健常群を含めた 3 群につき, 主と して免疫学的な生体影響に関する検討を行なった。
本工場はワンショット法によるポリウレタン製造工程 をとっており, 開設当初には, 作業環境気中 TDI 濃度 が $0.0861 \sim 0.8750 \mathrm{ppm}$ ときわめて高源度を認めたが， その後数次にわたる作業環境改善が行なわれ，本調查開 始時には各作業工程の TDI 濃度は, いずれも許容濃度 $0.02 \mathrm{ppm}$ 以下の状況にあった.

さて本調查対象の TDI による免疫フレルギ一的生体 影響については，次のような事実が認められた．すず本 調査の 5 年間にわたる低濃度 TDI 暴露環境下において は, 対象作業者 43 名には気管支喘息, 過敏性肺炎, 接 触皮苚炎なと TDI Kかかわる一連のフレルギ一疾患の 発生は一例る認めていない，次にアレルギー反応との関 連における末梢血液中好酸球数は, 従来 TDI 作業者に 和いて有意な増加を認めるとの報告 ${ }^{32}$ があるが， A， B およびC群のいずれにもその傾向はなく，また 3 群間の 成績には有意差がなかった。

次に IgE は局所の肥満細胞や好中球を感作し，ヒス タミン等の化学伝達物質を遊離することで，その生体に 対する種々のアレルギー状態を是う指標の一つとして知 られる. しかし TDI 暴露健常作業者や TDI にアレル ギ一反応を示す者においては，それらの血清 IgEの変動 には特異性がなく，陽性率む高くないとの報告むある. そこで Karol ら 22)は TDI の代わりに TMI と HSA を結合させた抗原を作成し, TDI 吸入誘発試験で陽性 の者に, 高率に RAST (tolyl specific IgE) の上昇を認 めたことを報告した，一方，城戸33）はその後の追試で TDI に過敏な作業者で RAST の上界を示した者はわず かであり，特異性は認められなかったと報告している。 本調查成績ではA群作業者 1 名に血清 IgE 高値の者を 認めたが，その他の検查所見との関連を含めて特記すへ き変化は認めなかった.このことは, 対象とした作業者 が低漊度長期（ 5 年以上）TDI 暴露作業者であり, 就 業当初には TDI による粘膜刺激症状を認めたとして る, 低濃度暴露の継続がかえって生体には一種の減感作 的作用として働くことも想定された. また芳原ら ${ }^{34)} の$ 行 なった TDI 業務就業期間別血清 IgE 值で, 経験年数 1 年末満の一部の作業者群が経験年数 1 年以上の作業者群 
に比べて著しく高値を示したことを報告しているが，こ れもひとつの減感作的作用の現われかもしれない，次代 A群作業者の一部に血清 IgG 高値の者を認めたがここ れが tolyl specific IgGの上昇によるすのか，あるいは

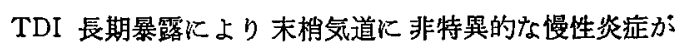
起こることが原因となるか忏明らかでない，慢性べリリ ウム睄症例に批いては，有意に血清 IgGの上昇を認め る者があるとの報告35〉があり，TDI 暴露者に括いて IgGの上昇を認める者についてさらに詳細な㛟討を行な こことが TDI 暴露による間質性肺病変の原因解明のた ぬに必要であると思われる。

さて次に，今回我々は MDI 拉よび TDI による過敏 性肺炎の報告4,9,24) を考虙して，類上皮性肉芽尰形成疾 患で産生される SACE, SLZM や，カラニゲン肉芽腫 で産生される GP-DAP について検討した.これらのう ら本対象では SLZM のみがA群作業者で高 值を示し た. SLZMは1922 年 Fleming によって発見 ${ }^{36}$ された ムコ多糖類を加水分解する醭素で, 別名ムラミターゼと る呼ばれている. 1966 年, Osserman らが単球性白血 病で血清中に SLZM が增加することを報告37)し，後に 肉芽庫性肺疾患においても上昇することが認められた。 SLZMは正常人では好中球，単球，マクロファーシに多 く存在する. SLZMの大部分は白血球に由来すると考兄 られるが，今回の研究成續ではA群作業者の SLZM は 末梢白血球数，単球数，好中球数等との関俰は認められ ずまた SACE，GP-DAP との関連性も認められなか った. このことより SLZM の上算は白血球数の增加や 肉芽腫形成からでは十分説明できず，したがって今回の SLZM の上昇は，TDI 吸入の化学的刺激あるいは生体 内への異物唚入刺激によるマクロファージ系細胞活性化 による影響か否かについてはさらに今後の検討に待ちた い. 次に TDI による肝機能障害については，1957 年に Zapp Б ${ }^{38)}$ の TDI 経口投与動物の一部に肝の脂肪沈着 を認め，我が国でも飯野 ${ }^{39}$ がマウスを用いTDI 蒸気を 吸入させることにより肝に脂肪沈着を認めたと報告して いる.乙かし人に和ける肝障害の報告はなく，腎機能障 害に関しては動物，人とるに報告されていない，我々の 本研究でも肝腎機能に異常を示す者はなかった.

\section{V. 結 論}

TDI 暴露作業者について血清免疫学的検討を行ない 次の評価を得た。

1）作業環境気中 TDI 潧度はいずれの工程において も常時 $0.002 \mathrm{ppm}$ 以下であった.

2）自覚症状，胸部X線検查では，TDI 暴露による
面接的な健康障害は認められなかった。

3）末梢血液娭查扰よび血液生化学検查では特記すへ き異常はなかった。

4）免疫グロブリン検查では $\operatorname{IgE}$ 值は变化を認めず， 一方 TDI 㨁接暴露群に掠いて IgG 值が高値を示す㑯 向を認めた。

5) SACE, SLZM， GP-DAP の検討では，SLZM が TDI 直接暴露者に扎いて高値を示す傾向を認めた。

\section{文献}

1) Brugsch HG, Elkins HB. Toluene di-isocyanate (TDI) toxicity. New Eng J Med 1963; 268:353357.

2) Sweet LC. Toluene-diisocyanate asthma. Univ Mich Med Cent Bull 1968; 34 : 27-29.

3) Pepys J, Pickering CAC, Breslin ABX, et al. Asthma due to inhaled chemical agents-Tolylene di-isocyanate. Clin Allergy 1972; 2 :225-236.

4) Charles J, Bernstein A, Jones B et al. Hypersensitivity pneumonitis after exposure to isocyanates. Thorax 1976; $31: 127-136$.

5) Cockroft DW, Mink JT. Isocyanate-induced asthma in an automobile spray painter. CMAJ $1979 ; 121: 602-604$.

6) O'brien IM, Harries MG, Burge PS, et al. Toluene di-isocyanate-induced asthma I : Reactions to TDI, MDI, HDI and histamine. Clin Allergy 1979; 9 : 1-6.

7) O'brien IM, Newman-Taylor AJ, Burge PS, et al. Toluene diisocyanate-induced asthma II : Inhala. tion challenge tests and bronchial reactivity studies. Clin Allergy 1979; $9: 7-15$.

8) Bernstein LL. Isocyanate-induced plumonary disease-a current perspective. J Allergy Clin 1982: $70: 24-31$.

9）藤村直樹，木野稔也，長井宛子ほか。ボリウレタン塗装 工にみられたインシフネートによる過敏性肺眬炎の 1 例. 日胸疾会誌 $1984 ; 22: 506-513$.

10)島 正吾. 職業アレルギ一性呼吸器疾患. 現代医学 $1970 ; 18: 81-99$.

11) Butcher BT, Salvaggio JE, Weill $H$, et al. Toluenediisocyanate (TDI) plumonary diseaseImmunologic and inhalation challenge studies. J Allergy Clin Immunol 1976; $58: 89-100$.

12) Axford AT, Mckerrow CB, Parryjones A, et al. Accidental exposure to isocyanate fumes in a group of firemen. Br J Ind Med 1976; $33: 65-71$.

13) Schmidt-Nowara WW, Murphy RLH, Atkinson JD. Lung function after acute toluene di-isocyanate inhalation. Chest 1973; $63: 1039-1040$.

14) Zapp JA. Hazards of isocyanates in polyurethane form plastic production. A M A Arch Ind Health $1957 ; 15: 324-330$.

.15) 西浦 環，谷 徽郎. Toluene-diisocyanate (TDI) Kよる皮庙障害. 皮潗々泌尿 $1963 ； 26: 56-63$.

16) Dernehl CU. Health hazard associated with polyurethane foams. JOM $1966 ; 8: 59-62$. 
17）田中健一. Toluene-diisocyanate (TDI) によるマウ ス接触過敏症营起の陚みについて。座業医学 1963；21： 456-457.

18）後藤友子，石津澄子．イソシアネート化合物の生体作用 人関する動物実験的研究：第IV報 TDI 释皮感作マウスの 昅入实臨. 日衛誌第51回総会発表 $1981 ； 453$.

19) Sheel LD, Killens R, Josephson A. Immunological aspects of toluene disocyanate (TDI) toxicity. Am Ind Hyg Assoc J 1964; 25 : 179-184.

20) Porter CV, Higgins RL, Scheel LD. A retrospective study of clinical physiologic and immu. nologic changes in workers exposed to toluene diisocyanate. Am Ind Hyg Assoc J 1975; 36 : 159168.

21) Avery SB, Stetson DM, Pan PM, et al. Immunological investigation of individuals with toluene diisocyanate asthma. Clin Exp Immunol 1969; 4: 585-596.

22) Karol $\mathrm{MH}$, Ioset $\mathrm{HH}$, Alarie $\mathrm{YC}$, et al. Tolylspecific IgE antibodies in workers with hypersensitivity to toluene diisocyanate. Am Ind Hyg Assoc J 1978; 39, 454-458.

23) Karol MH, Sandberg T, Riley EJ,et al. Longitudinal study of tolyl-reactive $\operatorname{IgE}$ antibodies in workers hypersensitive to TDI. JOM 1979; 21 : 354-358.

24) Zeiss CR, Kanellakes TM, Bellone JD, et al. Immunoglobulin E-mediated asthma and hypersensitivity pneumonitis with precipitating anti-hapten antibodies due to diphenylmethane diisocyanate (MDI) exposure. J Allergy Clin Immunol 1980; $65: 346-352$.

25) Kasahara $Y$, Ashihara $Y$. Colorimetry of angiotensin-I converting enzyme activity in serum. Clin Chem 1981; $27: 1922-1925$.

26）福井 萬，宮谷勝明. 比溜法を用いた血清りソチーム活 性の測定法煌関する検討。衙生検查 1978；27：1055-1058。

27) Nagatsu I, Hino $M$, Fuyamada $H$, et al. New chromogenic substrates for X-prolyl dipeptideylaminopeptidase. Anal Biochem 1976; $74: 466-476$.
28) U.S. Department of Health, Education, and Welfare, Public Health Services. Criteria for a recommended standard : Occupational exposure to toluene diisocyanate. Washington, D.C. : National Institute for Occupational Safety and Health, U.S. Department of Health, Education, and Welfare, $1973: 16-50$.

29) Konzen RB, Craft BF, Scheel LD, et al. Human response to low concentrations of $p$, p-diphenylmethane disocyanate (MDI). Am Ind Hyg Assoc J 1966; 27:121-127.

30) Bruckner HC, Avery SB, Stetson DM, et al. Clinical and immunologic appraisal of workers exposed to diisocyanates. Arch Environ Health $1968 ; 76: 619-625$.

31) Lapp NL. Physiological changes as diagnostic aids in isocyanate exposure. Am Ind Hyg Assoc J $1971 ; 32: 378-382$

32) Johnstone RT. Toluene-2,4-diisocyanate-clinical features. Ind Med Surg 1954; $26: 33-34$.

33）城戸照彦. TDI (toluene-diisocyanate) 喘息関する 研究. 労憉科学 $1983 ; 59: 45-58$.

34）芳原達也, 小林春男, 東原英治ほか。低湽度のトルエン シイソシフネート曝露が健康に及汪す影響，山口医学 $1981 ; 30: 87-91$.

35）吉田 退, 山田雅啓，加藤保夫ほか. 慢性ベリリウム肺 三症例の臨床的検討 : ベリリウム工場の健康管理 (26)，産 業医学 $1980 ; 22: 304$.

36) Fleming A. On a remarkable bacteriolitic element found in tissues and secretions. Proc Roy Soc B 1922; 93 : 306.

37) Osserman EF, Lawlor DP. Serum and urinary lysozyme (muramidase) in monocytic and monomyelocytic leukemia. J Exp Med 1966; 124 : 921.

38) Zapp JA. Hazards of isocyanates in polyurethane foam plastic production. AMA Arch Ind Health 1957; $15: 324-330$.

39）飯野房子. ボリウレタンフォーム制造工程の労㗢衙生学 的研究. 学働科学 $1963 ; 39: 356-365$.

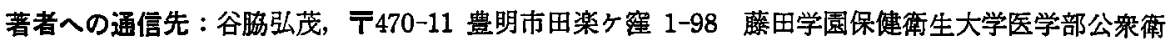

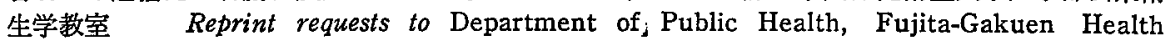
University School of Medicine, 1-98 Kutsukakecho, Toyoake, Aichi, 470-11 Japan (H. Taniwaki) 